APPLES IN STORE.

AppLEs always, whether in barrels or piles, when the
temperiture is rising so that the surrounding air is warmer than the apples, condense moisture on the surface and
become quile moist and sometimes dripping wet, and this has given the common impression that they "sweat," which is not true. As they cone from the tree they are plump
and solid, full of juice; by keeping, they gradually part with a portion of this moisture, the quantity varying with being much more rapid when first picked than after a short time, and by parting with this moisture they become in barrels; but this moisture never shows on the surface in the form of swetul. In keeping apples, very mich depends causes a change in the fruit, and bastens maturity and decay, and we should strive to bave as little clange as pos-
sible, and also bave the temperature as low as possible, so the apples do not freeze. Then, some varieties keep much
better in open bins than others; for instance, the Greening better in open bins than others; for instance, the Greening
is one of the best to store in bins. A very good way for storing apples is to have a fruit-room that can be made and
kept at from $32^{\circ}$ to $28^{\circ}$, and the air close and pure, put the apples in slatted boxes, not bins, each box bolding about one barrel, and pile them in tiers, so that one box above
rests on two below, and only barrel when ready to market; but this is an expensive way, and can only be practiced by those with limited crops of apples, and it is not at all
practicable for long keeping, because in this way they lose practicable for long keeping, because in this way they los barrels, and become badly sliriveled.

All things considered, there is no way of keeping apples
quite so good and practicable as packing in tight barrels and storing in cool cellars; the barrel forms a room within a room, and prevents circulation of air and consequent drying and shrinking of the fruit, and also lessens the changes
of temperature, and besides more fruit can be packed and stored in a given space than in any other way. The poorest of all ways is the large open bin, and the objections are: fruit; and too much trouble to bandle and sort when desirable to market. It was formerly the almost universal cus-
tom in Western New York to sort and barrel the apples as fast as picked from the trees, beading up at once and draw. ing to market or piliug in some cool place till the approach
of cold weather, and then putting in cellars. method it was impossible to prevent leaves, twigs, and other
dirt from getting into the bin, and it was difficult to prop-
erly sort the fruit, and if well sorted, occasionally an apple, with no visible ciuse, will entirely and wholly rot soon after packing. Some varieties are more liable to do this
than others, but all will to some extent; this occurs within a week or ten days after picking, and, when barreled, these decay others. Although packed ever so well and pressed
ever so tight, the shrinking of the fresh-picked fruit. sonn makes them lonse, and nol hing is so bad in bandling apples as this. Altogether this was a very untidy method of
bandling apples, and has been entirely abandoned for a better. quantity to be bandled; if only a few hundred barrels, they quantity to be handled; if only a few hundred barrels, they Place empty barrels on a log-boat or old sled; take out the
upper bead and place it in the bottom of the barrel; on picking the apples put them, without sorting, directly into
these barrels, and when a load is filled, draw to the barn these barrels, and when a load is filled, draw to the barn one tier is full lay some strips of boards on top and on these place another tier of barrels; then more boards and another an ordinary barn floor will in this way stere a good many barrels of apples. Where many bundreds or thousands of
barrels are grown, it is a good plan to build house: or sleds in convenient places in the orchard for holding the apples from the ground; floors, sides, and ends should be made of
strips about four inches wide and placed one inch apart, and the roof should project well on every side. The apples, carefully on the floors, about three feet deep. Where these
houses are not provided, the next best way is to pile the
apples, as picked, on clean straw under the trees in the apples, as picked, on cle
deepest shade to be found.

After lying in any one of these positions about ten days
they should be carefully sorted and packed in clean barrels, placing at least two layers on the bottom of the barrels, two or three times as the filling goes on, and, with some sort of press, press the head down, so that the apples shall
remain firm and full under all kinds of handling. Apples may be pressed too much as well as too little. If pressed
so that many are broken, and badly broken, they will soon get loose and rattle in the barrels, and nothing spoils them they shall be sure to remain firm, and carefully shaking so as to have then well settled together, has as much to do with their remaining firm as the pressing down of the head. be placed on their sides in a barn or shed, or in piles, cov-
ered with boards, from sun and rain or if a fruit-house or ered with boards, from sun and rain, or if a fruit-house or
cellar is handy they may at once be placed therein; the
object should be to keep them as cool and at as even a temperature as possible. In all the operations of handling apples from picking to market, remember that carelessness detracts much from its keeping and market value; and
remember another thing, that "Honesty is the best policy."
$-J$. S. Woodward, in N. Y. Tribune.

\section{ON DETERMINING THE SUN'S DISTANCE BY A NEW METHOD.}

By T. S. H. Eytrnge, Cainsville, Canada.

IT is well known that the sun's distance has been determined from the velocity of light. It has been found, by
terrrestrial experiments, about how fast light travels, and knowing from certain astronomical phenomena the time light requires to pass from the sun to
been able to determine the sun's distance.

There are several methods of determining the velocity of light, but hitherto only two plans have been used to detect the time light occupies in passing from the sun to the earth. This time was first discovered by observations of the satellites of Jupiter. It was found that the interval between the
eclipses of these bodies was not al ways the same-that the

eclipses occurred earlier when Jupiter was nearest the earth, $\mid$ the case of many of those pitiful botches one was, in fact,
and later when be was at his greatest distance. Roemer, a quite at a loss whether more to lament the want of underDanish astron he was at his greatest distance. Roemer, a quite at a loss whether more to lament the want of underDion. The second method by. which this time has been vent to the ijdignaticn one could not but feel at the arro
thene found is the aberration of stellar light. This refined method
was detected by the great English astronomer Bradley. About two years ago it occurred to me that a third method I had then, as on later occasions, repeatedly expressed my can be used to solve this important problen. My plan is just scorn of the contemptible clan. Darwin smiled at this
this: It is well known that many variable stars, such as and endeavored to calm me with the words, ' My dear young

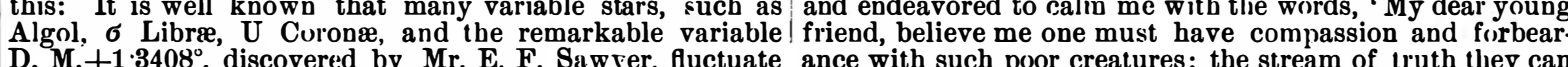

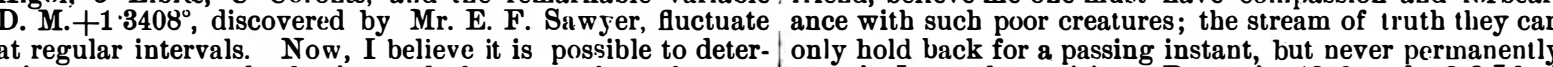
mive very accurately the intervals between these changes, stem.' In my later visits to Down in 18:6 and 18:9 I had and, by noting the clange of time in these intervals, when the pleasure of being able to relate to Darwin the mighty
the earth is in different points of its orbit, we get the time progress which in the past intervals his doctrines bad made inht requires to cross that orbit. For, as in the case of the progress which in the past intervals his doctrines bad made
Germany. Their decisive outburst happened more rapidly changes will occur earlier than when it is in conjunction or ateason chiefly that the power of social and religiuus prejuapproaching that point. I bave recently put this plan to dice is not nearly so strong here as among our cousins acros
and \begin{tabular}{l|l} 
In detecting the changes of variables. I have attempted & the Channel, who are better placed than ourselves. Darwin \\
was perfectly well aware of all this; though his knowledge
\end{tabular}

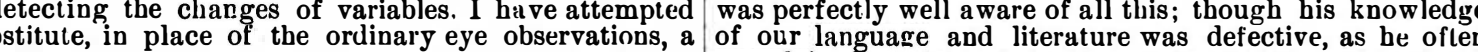
very delicate thermopile. which registers the changes in the
vart of our language and literature was defective, as be often
complained, yet he bad the highest appreciation of our intel-

PROFESSOR HAECKEL ON DARWIN.

Is Nature appears a report of the remarkable address
iven by Professor Haeckel at the recent Eisenach meeting iven by Professor Haeckel at the recent Eisenach meeting
of the German Association of Naturalists on the theories of Darwin, Goethe, and Lamarck. The address is mainly evoted to Darwin and Darwinism, and of both, we nee "When, five months ago, the sad intelligence reached us win had concluded lis life of rich activity there thrilled win had concluded lis life of rich activity there thrilled
with rare unanimity through the whole scientific world the dherents and scholars of the great naluralist lament the decease of the head master who had guided them, but even
he most esteemed of bis opponents had to confess that one of the most significant and influential spirits of the century loquent expression in the fact that immediately after his eath the English newspapers of all parties, and pre-emiGreat Britain, the national Temple of Fume, Westminster
Abbey; and there, in point of fact, he found his last resting place by the side of the kindred-minded Nerton. In no country of the world, however, England not excepted, has
he reforming doctrine of Darwin met with so much living as in Germany. It is, therefore, only a debt of hovor we pay if at this year's assembly of German naturalists and phywho has departed, and bring home to our minds the lofti-
ness of the theory of nalure to which he bas elevated us. And what place in the world could be more appropriate for rendering this service of thanks than Eisenach, with its As in this sacred spot 360 years ago Martin Luther, by lis new era in the bistory of civilization, so in our days has ment, constrained the whole perception, thought, and volition
of mankind into new and higher courses. It is true that more affinity to the meek and mild Melancbthon than to the powertul and inspired Luther. In the scope and importance, were entirely parallel, and in both the success marks a new epoch in the development of the human mind. Consider,
first, the irrefragable fact of the unexampled success which Darwin's reform of science bas achieved in the short space science bas any new theory penetrated so deeply to the foun-
dition of the whole domain of knowledge or so deeply affected the most cherished personal convictions of indivi. vehement opposition and so completely overcome it in such
short time. The depicture of the astounding revolution their entire view of nature and conception of the world will orm an interesting chapter in the future history of the docDescribing a visit which he paid to the late Mr. Darwin
De of develones. 1866, Professor Haeckel says:

"In Darwin's own carriage, which he had thoughtfully sunny morning in October through the graceful, billy landscape of Kent, which, with the checkered foliage of its
woods, with its stretches of purple leath, yellow broom, and evergreen oaks, was arrayed in the fairest autumnal dress.
As the carriage drew up in front of Darwin's pleasant counAs the carriage drew up in front of Darwin's pleasant counry-house, clad in a vesture of ivy and embowered in elms,
there stepped out to meet me from the shady porch, overthown with creeping plants, the great naturalist himself, a A tlas supporting a world of thoughts. his Jupiter-like foremild eyes looking forth under the sladadow of prominent
and deeply furowed by the po mental labor his kindy, mild eyes looking forth under the shadow of prominen
brows; his amiable mouth surrounded by a copious silver-
white beard. The cordial, prepossessing expression of the white beard. The cordial, prepossessing expression of the woce, the natural and naive train of ideas which marked bis conversation, captivated my whole beart in the first hour of our meeting, just as bis great work bad formerly, on my first
reading it, taken my whole understanding by storm. I fancied a lofty world sage out of Hellenic antiquity-a Socrates
or A ristotle-stood alive before me. Our conversation, of course, turned principally on the subject which lay neares the bearts of both-on the progress and prospects of the his-
tory of development. Those prospects at that time-16 years ago-were bad enough, for the highest authorities bad for the mont part set themselves against the new doctrines. With touching modesty, Darwin said that his whole work
was but a weak attempt to explain in a natural way the origin of animal and vegetable species, and that he should not
live to see any noteworthy success following the experiment live to see any noteworthy success following the experiment,
the mountain of opposing prejudice being so ligh. He hought I had greatly overestimated his small merit, and that the high praise I had bestowed on it in my 'General Morphology, was far too exaggerated. "We next came to speak of the numerous and violent
attacks on his work, which were then in the ascendant. In
A CATALOGUE containing brief notices of many important
scientific parers heretofore published in the SUPPLEMENT, nay be bad gratis at this office.

TI T

\section{Scientific American Supplement.} PUBLISHED WEEKLY.

Terms of Subscription, $\$ 5$ a Year.

Sent by mail, postage prepaid, to subscribers in any part of paid, to any foreign country.
.

All the back numbers of The SUPplement, from the All January 1, 1876, can be had. Price, 16

All the back volumes of The Supplement can likewise be supplied. Two volumes are issued yearly. Price of each volume, $\$ 2.50$, stitched in paper, or $\$ 3.50$, bound in

Combined Rates - One copy of Scientific American and one copy of Scientific American Supplement, on ear, postpaid, $\$ 7.00$

A liberal discount to booksellers, news agents, and can

MUNN \& Co., Publishers,

261 Broadway, New York, N. Y.

TABIAE OF' CONTEN'TS.

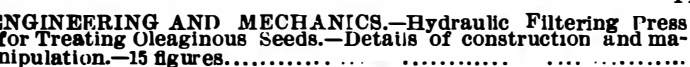

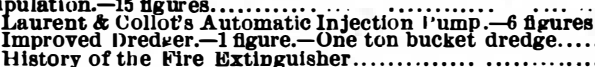

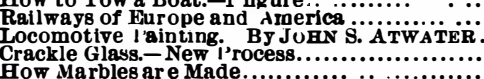

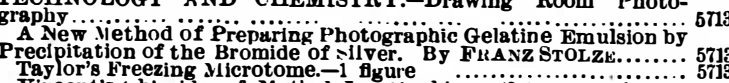

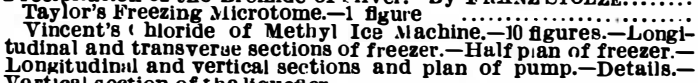

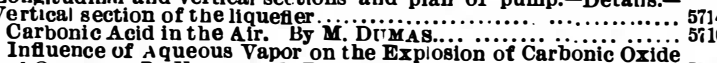

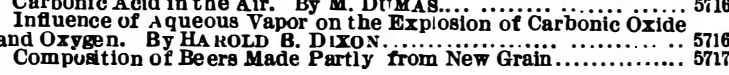
II. BOTANY, HORTICOLTURE, ETC.-Double Buttercups.

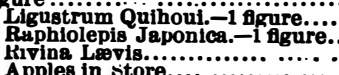

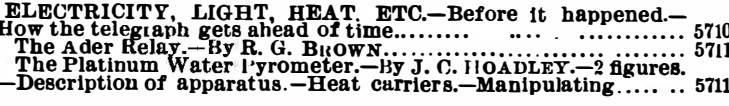

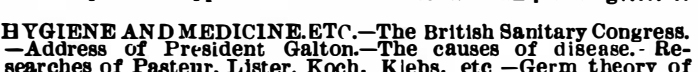

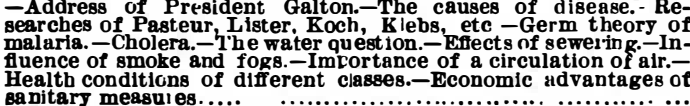

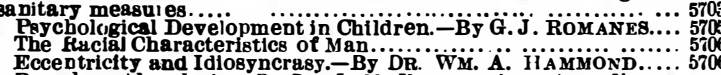

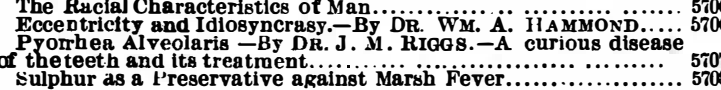

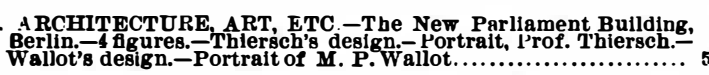

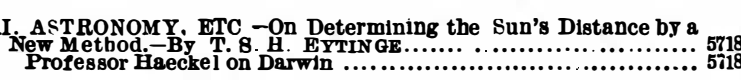

PATENTS.

In connection with the Seientifle American, Messrs. Mons \& $C_{0}$ are Solicitors of American and Foreign Patents, have had 35 years experiA special notice is made in the Sclentific American of all Inve tions patented through this Agency, with the name and residence of the
Patentee. By the immense circulation thus given, public attention is diected to the merics of the new patent, and sales or introduction often asily effected.

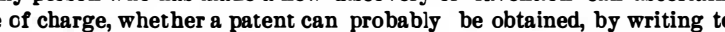

We also send free our Hand Book about the Patent Laws. Patents, Caveats. Trade Marks, their costs. and how procured, with hints for MUNN \& CO., 261 Broadway, New York. Branch Office, cor. F and 7th Sts., Washington, D.C. 